\title{
Teatr bohatera popularnego Europy Zachodniej a polska szopka kolędnicza
}

Streszczenie: Od XVIII w. zaczął zyskiwać popularność szereg postaci lalkowych, które pojawiły się na wędrownych scenkach trup teatralnych niemal w całej Europie. Były to postaci komiczne o charakterze bohaterów popularnych, przemawiające do publiczności ulic, placów, targów - ich własnym językiem. Część z nich wywodziła się z komedii dell'arte (Pulcinella, Poliszynel, Guignol, Don Cristobal, Pietruszka). Korzenie teatralne bohaterów, którzy pojawili się z państwach niemieckich (Hanswurst, Kasperle, Kašparek, Gašparko), sięgają teatru elżbietańskiego i wiążą się z obecnością wędrownych trup angielskich aktorów, które włączyły do swoich przedstawień tradycyjną postać błazna. Ponieważ dla Polski jest to czas powolnej utraty niepodległości na rzecz państw ościennych, teatr bohatera ludowego nie powstał. Rozwinęła się za to forma szopki kolędniczej. Porównanie funkcji i znaczenia tych zjawisk teatralnych jest przedmiotem tego opracowania. Jest to także próba zwrócenia uwagi pedagogów na edukacyjne walory polskiej szopki kolędniczej.

Słowa kluczowe: szopka, teatr lalek, sztuka popularna, bohater ludowy, teatr dziecięcy, kabaret

\section{Wprowadzenie}

Teatr lalek istniał równolegle do teatru aktorskiego od zarania dziejów. Wszędzie tam, gdzie żywego człowieka zastępowała forma plastyczna - rzeźba, maska, marionetka - można mówić o teatralnych formach animacyjnych. A jednak do końca XVII w. teatr lalek nie wytworzył specyficznego nurtu teatralnego, nie zasłużył na odrębne miejsce w sztuce, a lalkarze stali jeszcze niżej w hierarchii społecznej niż aktorzy.

Na przełomie XVII i XVIII w. w Europie istniały dwie odmienne konwencje teatralne. Na kontynencie królowała włoska commedia dell'arte, zaś na Wyspach Brytyjskich - teatr elżbietański. Obie te konwencje zrodziły formę teatru lalek, który stał się rozrywką popularną, a jej centrum stanowiła postać 
bohatera wywodzącego się z ludu. Ponieważ ta forma teatru jest w Polsce bardzo mało znana, a okazała się niezwykle trwała - w wielu miejscach istnieje do dziś - warto przyjrzeć się jej bliżej. Warto to zrobić także z innego powodu - zastanowić się, czy w Polsce odnaleźć można analogiczną formę teatru wywodzącego się z ludowej tradycji, który stał się własnością wszystkich.

\section{Commedia dell'arte}

Włoska komedia sięga korzeniami do starożytności. Z rzymskiego teatru farsowego (np. fabula atellana) zapożycza postaci, które mają charakter typów ludzkich, charakterów. Równocześnie rodzi się ona z tradycji wędrownych aktorów, mimów, którzy grali swoje widowiska na ulicach, placach, targowiskach, a co za tym idzie, musieli dostosować swoje działania do wymogu tych miejsc - mało tekstu, dużo ruchu. Przedstawienia złożone były z krótkich, improwizowanych scenek satyrycznych, które cechowała z jednej strony rubaszność, z drugiej akrobatyczna sprawność aktora.

Jeśli jednak commedia dell'arte wywodzi się od wędrownego mima, który często posługiwał się lalkami, to nie byłoby niczym dziwnym, gdyby i w przedstawieniach włoskiej komedii lalki też się pojawiły. I okazuje się, że tak właśnie było. Polscy widzowie też mogli to zaobserwować - Henryk Jurkowski w swoich Dziejach teatru lalek w Europie przytacza informację Kłokockiego, który pisze w Diariuszu sejmowym z 1666 roku, że występująca w Polsce trupa komediantów włoskich oferowała przedstawienia i aktorskie, i lalkowe (Jurkowski, 1970, s. 117). Kiedy więc w XVIII w. włoska konwencja teatru improwizowanego zaczęła się wyczerpywać i zastąpiona została komedią literacką, teatrem salonowym, operą - właśnie teatr lalek zaczął rozwijać swoją formę teatru bohatera popularnego, ludowego błazna, w którym bez trudu odnaleźć można postaci commedii dell'arte.

Szczególne znaczenie miał w tym procesie Pulcinella, postać sprytnego służącego (zanni), który tym różnił się od pozostałych (Arlekina, Brighelli, Pedrolina itp.), że był typem niejednorodnym i niejednoznacznym. Z jednej strony było to garbate indywiduum $\mathrm{z}$ obwisłym brzuchem, o wielkim nochalu, niskim czole, z wielką brodawką na brwi, co nadawało mu wyraz tępej brutalności. Na głowie nosił stożkowaty kapelusz, a kaftan zdobiły kolorowe wstążki i galony (Nicoll, 1967). Z drugiej strony, był on tępym, wulgarnym wieśniakiem z okolic Neapolu, który występował w wielu rolach: przede wszystkim jako służący, ale czasami bywał też piekarzem, handlarzem nie- 
wolników, oberżystą, malarzem, nawet głową domu i kochankiem. Alardyce Nicoll pisze: „Przy takiej różnorodności mała była możliwość, by przedstawić go konsekwentnie jako wyraźne indywiduum. Główna z cech jego odezwań polegała, zdaje się, na pewnym rodzaju głupkowatego dowcipu lub dowolnej głupoty, w istocie swej niewybrednej i wulgarnej, często wyrażającej się w brutalnych porównaniach, w których szlachetniejsze uczucia i sprawy duchowe były mieszane z błotem. Neapolitańska widownia nie interesowała się jego charakterem; raczej rozkoszowała się, słuchając prostackich gaf i brutalnych porównań, robionych w najrozmaitszych okolicznościach, i nigdy nie martwiła się, że jednego dnia Pulcinella występował jako tchórzliwy i łatwowierny dureń, a drugiego - jako śmiały, złośliwy i zdobywający sukcesy hultaj" (Nicoll, 1967, s. 72).

A zatem była to postać na tyle niedookreślona, że z łatwością mogła przyjmować na siebie różne cechy - we Francji Pulcinella stawał się Poliszynelem, w Anglii - Punchem, w Hiszpanii - Don Cristobalem, a w Rosji - Pietruszką. Dobrze ilustruje to na pół legendarna opowieść o włosko-francuskim lalkarzu Jeanie Brioché . Prawdopodobnie pierwotnie nazywał się on Giovanni Briocci i wykonywał usługi dentystyczne, wykorzystując lalkową postać Pulcinelli. Kiedy jednak trafił do Francji, jego nazwisko zmieniło brzmienie na bardziej francuskie ${ }^{2}$, a jego sławna marionetka dostała nowe imię - Poliszynel. Ta lalkowa postać zyskała we Francji tak ogromną popularność, że nawet historycy teatru (Charles Magnin, Jacques Chesnais) przekonywali o jej czysto francuskim pochodzeniu.

Henryk Jurkowski (1970) zauważa, że Poliszynel - podobnie jak Pulcinella - był „żywą gazetą” lub raczej żywym redaktorem, a jego specjalnością były skandale. Walory satyryczne i parodystyczne Poliszynela wykorzystywano na ulicach i placach, ale także na dworach i salonach arystokratów. Powstał też specyficzny rodzaj teatralnej parodii samego teatru. W czasie Wielkiej Rewolucji Francuskiej 1789 roku lalka Poliszynela została zgilotynowana, jako przedstawiciela (choć à rebour), starego porządku.

1 Jean Brioché (1567-?) był protoplastą rodu lalkarzy znanych we Francji pod nazwiskiem Datelin. Francuscy badacze nie znają dokładnych losów Brioché, ani powodu zmiany nazwiska, ale i oni potwierdzają włoskie pochodzenie tego rodu, por. http://www.biusante.parisdescartes.fr/sfhm/hsm/HSMx2006x040x002/HSMx 2006x040x002x0203.pdf.

2 Porzucił wkrótce swoją profesję wyrwizęba na rzecz lalkarstwa, które przyniosło mu dużo większą popularność. 

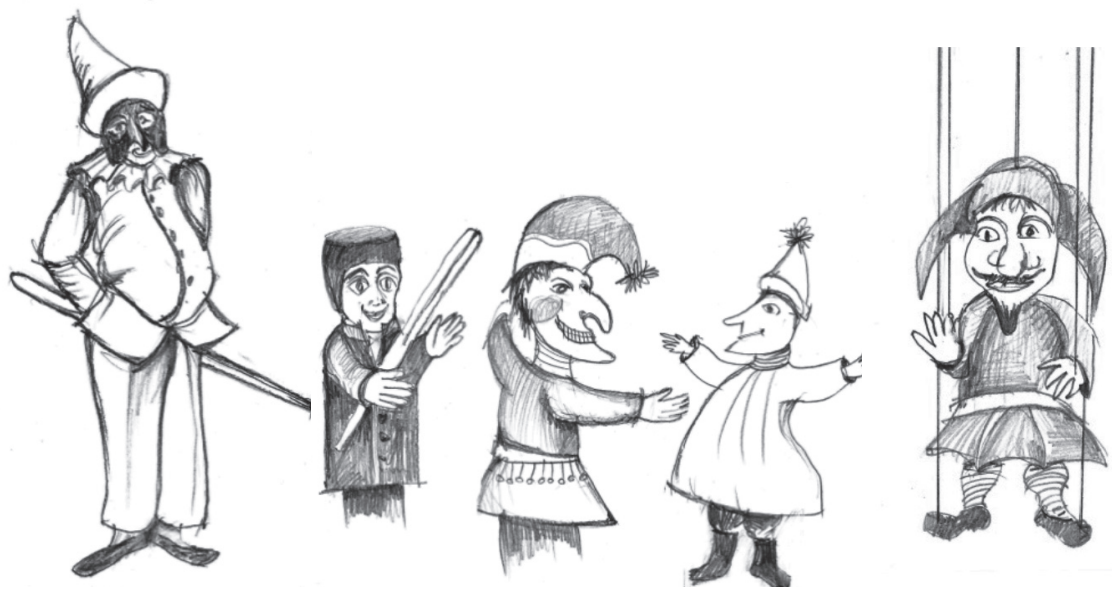

1. Pulchinella, postać z komedii dell'arte; 2. Gugnol, Punch i Pietruszka wywodzące się od Pulchinelli (pacynki); 3. Kašparek - czeska postać marionetkowa wywodząca się z wędrownych trup angielskich aktorów (rys. E. Tomaszewska)

Niedługo potem to puste miejsce zajął Guignol, który za sprawą Laurent'a Mourguet'a reprezentował już zupełnie nowy świat. Guignol nie był już służącym, lecz - na wzór swojego twórcy - lyońskim tkaczem. Był postacią dobrego serca, choć też bez zbytnich moralnych skrupułów, ignorantem, ale z poczuciem rozsądku, klepał biedę i był wykorzystywany przez swoich skąpych pracodawców, ale zachowywał poczucie humoru (choć często dość prymitywne) i hart ducha. Stał się więc Guignol przedstawicielem francuskiej ulicy, reprezentując zwykłego człowieka - mówił jego językiem i o jego sprawach. Czasem zaangażowany społecznie, w innych przedstawieniach charakteryzował się raczej dobrotliwym humorem czy parodiował znane motywy teatralne. Ale tak to jest z bohaterami ludowymi - żyją zmiennym życiem, odpowiadając na problemy i potrzeby swojej publiczności. Niezwykła jest żywotność Guignola, który nadal grywa na francuskich scenach i scenkach (np. w Théâtre Maison de Guignol w Lyonie).

Inną postacią, której protoplastą był włoski Pulcinella, jest angielski Punch. W 1662 r. Samuel Pepys opisał w swoich Dziennikach przedstawienie lalkowe z udziałem Pulcinelli zagrane przez włoskiego lalkarza, Pietro Gimonde z Bolonii, które okazało się ówczesnym hitem - Gimonde wystąpił nawet w Whitehall w obecności króla (Jurkowski, 2014, s. 150). Włoski lalkarz posługiwał się drewnianymi marionetkami, czyli lalkami prowadzonymi z góry, poprzez drut umocowany w głowie oraz poprzez sznurki poruszające 
ręce. Jednak na ulicach w Anglii (także innych krajów) rozpowszechniona była inna technika lalkowa - lalka rękawiczkowa (pacynka) prowadzona od dołu. Punch przyjął więc cechy włoskiego Pulcinelli, ale przeniósł je w rzeczywistość londyńskiej ulicy ${ }^{3}$. Ulica uformowała charakter tej postaci, jak i historię, którą - od tamtych czasów do dziś - opowiadają angielscy punchmani (Edwards, 2011). Zresztą i samo imię ma prawdopodobnie włoskie korzenie - prości ludzie mieli trudności z wypowiadaniem i zapamiętaniem włoskich czy francuskich imion, jak Pulcinella właśnie, więc zaczęli je modyfikować: Polcinella - Polichinelli - Punctionella - Polichinallo - Punchinnonella aż nadali mu brytyjsko brzmiące imię wiążące się z jego zamiłowaniem do zadawania ciosów kijem ${ }^{4}$ - Punchinello, co ostatecznie zostało skrócone do prostego - Punch.

Punch jest postacią brutalną, agresywną i arogancką, która nie przestrzega żadnych zasad. A mimo to - choć to wielu dziwi - teatr ten spełniał też funkcje terapeutyczne. Nie jest łatwo to wytłumaczyć, bo angielski Punch nie ma moralnych ograniczeń, ale realizuje on w przestrzeni sceny małego teatrzyku ulicznego nasze ludzkie nieuświadomione i mroczne pragnienia czy podejrzane potrzeby. Jest jakby kozłem ofiarnym, który przyjmuje na siebie nasze frustracje, grzeszne pragnienia i daje im upust w przedstawieniu. Poprzez uczestnictwo w spektaklu można się zatem wyładować, mówiąc metaforycznie - oczyścić, a warto podkreślić, że jest to oczyszczenie przez śmiech.

Wydaje się, że wszystkie postaci tego typu spełniały podobną rolę. Nie tylko te wywodzące się z włoskiej komedii, jak Pulcinella (bo we Włoszech nadal żyje lalkowa postać o tym imieniu), Poliszynel, Guignol, Punch, a także już młodsi - rosyjski Pietruszka (z końca XIX w.) czy hiszpański Don Cristobal, wprowadzony na scenę przez Federico G. Lorcę (Szopka Don Cristobala, 1930). Chodzi tu także o niemieckie postaci błaznów jak Hanswurst czy Pickelhärrig, który zastąpiony został później przez Kasperla.

3 Należy podkreślić, że bohater popularny, który rozwinął się z postaci commedii dell'arte, także na kontynencie grany był za pomocą pacynek. Kiedy i w jaki sposób doszło do zamiany marionetki na lalkę rękawiczkową - trudno powiedzieć. Można jednak przypuszczać, że przypadek Puncha będzie tu dobrym przykładem takiego zjawiska.

4 Atrybutem Puncha, podobnie jak jego braci z Francji, Włoch, Hiszpanii, a nawet Rosji, była pałka, którą z upodobaniem okładał swoich przeciwników. Takie teatralne lalkowe sceny bijatyki dostały nawet specjalną nazwę - bastonada od francuskiego: bâton - kij. 
Do tej grupy należy też postać czeskiego Kašpárka czy słowackiego Gašparko (ich pokrewieństwo jest widoczne). Cała ta grupa ma rodowód zgoła inny - wiąże się on z występami trup angielskich aktorów.

\section{Teatr elżbietański}

Konwencja angielskiego teatru okresu panowania Elżbiety I Tudor zrodziła się - podobnie jak włoska komedia improwizowania - z doświadczeń wędrownych trup aktorów, którzy prezentowali swoje widowiska na placach i targach, a zwłaszcza w obszernych angielskich oberżach. Tam, wykorzystując naturalny układ przestrzenny zajazdu, uformowała się słynna scena trójdzielna, tam także autorzy sztuk i aktorzy jednocześnie nauczyli się zaspokajać potrzeby artystyczne zarówno gawiedzi, zgromadzonej na dziecińcu, jak i ludzi wykształconych i arystokracji zasiadających na galeriach. Pod tym względem twórcy teatru elżbietańskiego nie mieli sobie równych. Wprowadzili do literatury teatralnej wiele motywów, które okazały się niezwykle inspirujące i pozostały żywe w sztuce do dziś dnia (Faust, Makbet, Romeo i Julia).

Niezwykła popularność teatru w Anglii na przełomie XVII i XVIII w. spowodowała dużą konkurencję teatralnych trup, z których wiele postanowiło szukać szczęścia także na kontynencie. Niestety, w większości niewykształcona publiczność europejska tego okresu - wstrząsana wojnami religijnymi (np. wojna 30-letnia) i morowym powietrzem, nie oczekiwała od teatru filozoficznych rozważań, ale przede wszystkim rozrywki. Dlatego aktorzy, aby móc się utrzymać, musieli zmienić swoje przedstawienia - uprościli repertuar, stawiając na sceny efektowne dla publiczności ${ }^{5}$, a filozoficzne dywagacje zastąpili prostym ludowym systemem wartości reprezentowanym przez sprytnego służącego, błazna wywodzącego się z ludu. Postać ta spełniała początkowo także rolę tłumacza, bowiem aktorzy grali przecież po angielsku. Był to więc służący „stąd”, miejscowy, który nie tylko tłumaczył, co dzieje się lub co będzie się działo na scenie, ale także komentował wydarzenia, często z satyrycznym zacięciem, oraz dokonywał oceny moralnej swoich panów, np. w Fauście czy Don Juanie. Jednocześnie żywych aktorów zastąpiono lalkami (najczęściej marionetkami). Powstałe postaci w wyniku dostosowania do potrzeb przybliżyły się formą do tych, które wywodziły się z commedii dell'arte.

5 Np. Faust czy Don Juan byli porywani do piekła przez diabła w oparach siarki i w ogniu, z wyciem dusz potępionych, które to sceny robiły na publiczności wielkie wrażenie. 
W ten sposób powstała przebogata galeria postaci lalkowych, pacynkowych i marionetkowych, które szczyt popularności zyskały na przełomie XVIII i XIX w. Niektóre z nich, jak Kašpárek, zaangażowały się w sprawy narodowe: „Kašpárka można by uznać za kopię niemieckiego Kasperla, gdyby nie fakt, że w wyniku przekory zdarzeń stał się czynnikiem utwierdzającym odrębność narodową Czechów. Mówił po czesku - przypominał i utwierdzał język czeski w świadomości ludu we wszystkich zakątkach kraju" (Jurkowski, 1970, s. 152).

\section{Polska szopka kolędnicza}

Jak widać z powyższego przeglądu - w całej Europie istniały, a często istnieją po dziś dzień, teatry, których osią są postaci lalkowe pełniące funkcję wywodzącego się z ludu bohatera popularnego, przemawiającego do publiczności ich własnym językiem, poruszające sprawy ich świata i jednocześnie pokazujące rzeczywistość w krzywym zwierciadle satyry. Niektóre z nich wywodzą się od postaci stricte teatralnych, inne - od ludowych, ale wszystkie przybierają podobne formy i posiadają podobne cechy, stając się jednocześnie własnością narodu, dla którego występują. A w Polsce?

Nie znajdziemy ani takiego teatru, ani takiej postaci, mimo że występy lalkarzy prezentujących różnego typu przedstawienia lalkowe znane były w całej Polsce. Stało się tak, gdyż okres największej popularności teatru bohatera popularnego przypadł na czas powolnego upadku Rzeczpospolitej zakończonego w 1797 r. całkowitą utratą bytu państwowego. Być może właśnie dlatego, że teatr ten przybywał do nas z Niemiec, Austrii i Rosji, Polacy nie mogli go zaakceptować. Miarą tego zjawiska może być historia z postacią Kubusia, którą w latach międzywojennych próbował rozpropagować miłośnik lalkarstwa, Jan Izydor Sztaudynger. Mieszkał on wówczas w Poznaniu, a w Wielkopolsce znana była tradycja niemieckiego teatru lalek. Chodziło zatem o stworzenie polskiej postaci bohatera popularnego, aby odciąć się od tradycji niemieckiej: „Teatr poznański, i tylko poznański, wzorował się na niemieckim. Szło o to, aby przeciąć tę pępowinę. Z inicjatywą w tym kierunku wystąpił Wincenty Ostrowski, instruktor Wydziału Oświaty Pozaszkolnej z kuratorium poznańskiego i niemieckiego Kasperla przezwał Kubusiem" (Sztaudynger i Kaliszewiczowa-Sztaudynger, 2009, s. 211). Mimo wielu starań Sztaudyngera Kubuś nie znalazł swojego odrębnego miejsca w tradycji lalkarstwa polskiego. Działania te spotkały się z całkowitym brakiem zrozumienia ze strony środowiska lalkarzy polskich, ale także i publiczności, która nie 
zaakceptowała tej postaci. Jak się wydaje, niechęć do obcych wpływów spowodowała, że wiek XIX stał się okresem rozkwitu przedstawień szopkowych, które traktowano jako rodzimą tradycję.

Skąd wzięła się szopka? Wydaje się, że jej korzenie sięgają kilku różnych tradycji. Z jednej strony uważa się, że szopka wyodrębniła się z urządzanego w kościołach żłóbka ${ }^{6}$. Inną tradycją, akcentowaną przez badaczy, jest średniowieczne misterium na Boże Narodzenie, jeszcze inną uruchamianie figur w ołtarzu szafiastym (retablo) (Jurkowski, 1970). Geneza szopki wiąże się więc z tradycją religijną. Należy tu jednak zwrócić uwagę, że podobnie jak to się działo w misterium aktorskim, tak i w misterium lalkowym z czasem coraz więcej miejsca zajmowały scenki o charakterze świeckim. Można nawet pokusić się o stwierdzenie, że właśnie te scenki były najbardziej atrakcyjne i popularne wśród publiczności.

Polska szopka kolędnicza charakteryzowała się pewnymi oryginalnymi cechami, które pozwalają jej zająć wyjątkowe miejsce w XIX-wiecznym teatrze lalek. Przedstawienia grane były przez grupy kolędników chodzących od domu do domu - zimowa pora nie sprzyjała występom ulicznym. Wykorzystywano lalkę na patyku, tj. kukłę, która była wyjątkową techniką animacyjną wśród marionetek czy pacynek wykorzystywanych w pozostałych częściach Europy. Na przełomie lat pięćdziesiątych XIX w. ustalił się architektoniczny kształt szopki - najbardziej okazałymi były dwukondygnacyjne, bogato zdobione, z dwoma kilkupiętrowymi wieżami z boków (jak szopki krakowskie); uboższe - składały się zwykle z dwóch czworobocznych wieżyczek. Pomiędzy nimi znajdował się żłóbek nakryty dachem, a przed nim w rowku prowadzone były lalki: „Dowcipny szopkarz wysuwa z boków ścian na scenę różne lalki drewniane lub papierowe. Obraca je, gada za nich, wyprawia różne figle, wprowadza rozmowy częstokroć tak śmieszne i naiwne, że pierwszy raz widzący tak dobrze uśmiać się może, jak na jakiej scenie komicznej teatralnej" (za: Wierzbowski, 1990, s. 21).

Przedstawienie złożone $\mathrm{z}$ wielu krótkich, często niepowiązanych ze sobą scen miało budowę otwartą - można było dołączać dowolną liczbę scenek i modyfikować je według potrzeb chwili - nie wpływało to na całość przedstawienia. Gdy przyjrzymy się starym tekstom szopkowym ${ }^{7}$, zobaczymy

6 Tradycja ta sięga XIII w. i wiąże się ze zorganizowaną przez św. Franciszka z Asyżu procesją wiernych do symbolicznego miejsca narodzin Chrystusa, którym była szopka zbudowana w wiosce Greccio koło miasta Rieti (1223).

7 Teksty szopkowe zbierane przez etnografów na przełomie XIX i XX w. drukowano w miesięczniku geograficzno-etnograficznym „Wisła” oraz na łamach „Ludu”. 
w nich mieszkańców wsi i miasteczek w sytuacjach, które z pewnością nie były rzadkie: scena bójki chłopów, scena z Żydem leczącym pobitego chłopa, scena z Druciarzem, który naprawiając garnki, śpiewa piosenkę o swoim losie itp. Sceny te mają charakter obyczajowych obrazków. Teatr ten miał również charakter środowiskowy - kolędnicy przygotowywali swoje przedstawienia dla konkretnych odbiorców, a ich scenki z pewnością nosiły piętno konkretnych osób czy sytuacji znanych powszechnie w danym środowisku i - jak można sądzić - rozpoznawanych przez publiczność w trakcie grania przedstawienia, co było źródłem śmiechu i zabawy. Dowodem na takie powiązania są scenki ze Strażakiem, Górnikiem, Majtkiem, Rybakiem, Kominiarzem. Pojawiają się tu bowiem zawody charakterystyczne dla danego regionu lub takie, które mają szczególne znaczenie dla danego środowiska.
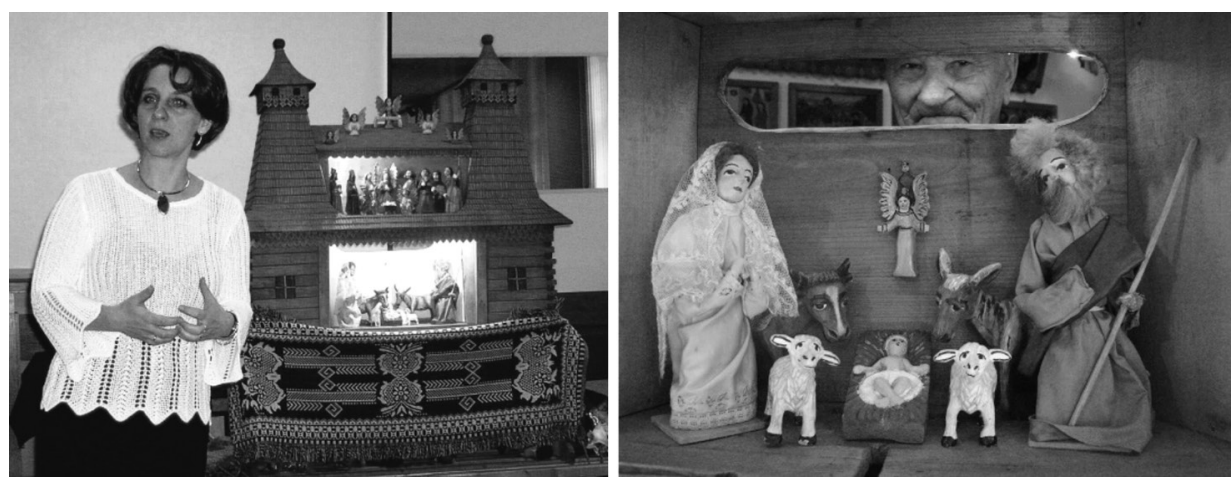

1. Ewa Tomaszewska z szopką Józefa Hulki prezentowaną w ramach seminarium Miejsce ludowej szopki kolędniczej w polskiej tradycji i w edukacji. Filia UŚ Cieszyn 7.01. 2004 (fot. $\mathrm{z}$ archiwum E. Tomaszewskiej).

2. Józef Hulka zaglądający na scenę swojej szopki; w podłodze rowki, w których prowadzone są kukiełki (fot. ze zbiorów ROK w Bielsku-Białej).

W szopkach pojawiały się także scenki o charakterze magicznym, z postaciami czarownic, diabłów czy aniołów, które wyraźnie nawiązują do symboliki obrzędów astronomicznego przesilenia zimowego. Jeszcze inną grupą są scenki intermedialne, jak te z Cyganem czy Kozakiem, którzy prezentują publiczności sztuczki z Niedźwiedziem prowadzonym na łańcuchu. Znajdziemy także scenki o charakterze patriotycznym, jak ta z Krakowiakiem i Krakowianką, które to postaci dość łatwo zidentyfikować jako Polaka i Polkę, a także ilustracje znanych piosenek (np. scena z Huzarem i Małgorzatką). Ciekawym przykładem podanym przez Stanisława Estreichera jest wprowa- 
dzenie do szopki krakowskiej fragmentów ze sztuki Władysława Anczyca Kościuszko pod Racławicami (Jurkowski, 1970).

Pozostałością po pierwotnych religijnych korzeniach szopki kolędniczej są sceny herodowe oparte na przekazie biblijnym. Trudno znaleźć szopkę polską bez tych, choćby kilku scen przedstawiających Heroda, który „za swe zbytki” zostaje ukarany przez Śmierć i porwany do piekła przez Diabła. Zresztą liczba scen i motywów biblijnych też jest różna. Wszystko to pokazuje, że kolędnicy nie traktowali swoich przedstawień rygorystycznie: „Kompozycja tekstów szopkowych oparta na procesji postaci pozwalała na ich wymianę, na wprowadzanie nowych postaci i scen. Przyswajanie takich elementów w wieku XIX odbywało się dwiema drogami: przez włączanie najpopularniejszych motywów z teatru żywego lub powszechnie śpiewanych kupletów oraz przez wprowadzanie starannie wybranych postaci z pobudek satyrycznych i patriotycznych. Proces ten odbywał się spontanicznie, głównie z inicjatywy samych szopkarzy" (Jurkowski, 1970, s. 79).

A zatem polskie przedstawienia szopkowe nie posiadały jednego bohatera popularnego, ale całą galerię barwnych postaci z różnorodnymi odniesieniami - to był nasz bohater zbiorowy reprezentujący wszystkie warstwy społeczne. A że najczęściej postaci szopkowe wiązały się ze środowiskami wiejskimi, to było efektem bardzo powoli ustępującego feudalizmu, którego ślady istniały jeszcze długo w XX-wiecznej Polsce. Nie znaczy to jednak, że tradycja „chodzenia z szopką" nie występowała w miastach. Dotyczyła ona zarówno klas stojących najniżej w społecznej hierarchii, jak i klas średnich i wyższych widać to na zachowanych rycinach ${ }^{8}$. Jest to więc tradycja wszystkich Polaków.

Warto dodać, że po przegraniu powstań ochrona języka i manifestowanie odrębności kulturowej były istotnym zadaniem teatru lalek, który dzięki swojemu ludowemu charakterowi nie podlegał takiej kontroli jak zawodowe sceny aktorskie dławione cenzurą (Jurkowski, 2003). W ten sposób w szopce kolędniczej pojawiały się także wezwania do walki niepodległościowej czy przypomnienie chwały oręża polskiego. Obecność szopkarzy, ich gra utrzymywały naszą tożsamość narodową w czasach utraty państwowości i prowadzonej przez zaborców agresywnej polityki depolonizacyjnej. Polski lalkowy teatr popularny spełniał zatem podobne funkcje co europejski (np. czeski teatr Kašpárka).

8 Znany jest np. rysunek gwaszem J. P. Norblina Jasetka w pałacu na Powązkach, który nie tylko pokazuje lalkarzy z kukiełkami za parawanem, ale przede wszystkim widzimy arystokratyczną publiczność, a na stalorycie Jasełka w Polsce na widowni zasiada szlachta. 
Podobnie jak teatry lalek całej Europy - szopka posiadała duży ładunek satyry, parodii, a jej forma okazała się niezwykle atrakcyjna dla pierwszych polskich kabaretów. Warto przypomnieć krakowski „Zielony Balonik”, który bezceremonialnie wykorzystał nie tylko strukturę tekstu, formę przedstawienia (lalkowe variété), ale i funkcje postaci lalkowych (np. lalka przedstawiająca ówczesnego prezydenta miasta Krakowa, Juliusza Leo, obsadzona została w roli Heroda, lalka malarza Jacka Malczewskiego przedstawiała go w karykaturalnej postaci satyra, zapożyczonej z jego własnych dzieł).

Także formujący się w XX w. polski teatr lalek i teatr dla dzieci zaczął od ścisłych związków z formą szopki kolędniczej. Ostatecznie jednak nie powinno to nikogo dziwić, gdyż szopka kolędnicza tworzona była w przytłaczającej większości przypadków przez dzieci i młodzież. Ryszard Wierzbowski pisze: „Przez dwa wieki, bo taki okres życia szopki kolędowej mamy dotąd udokumentowany, na ziemiach polskich istniał teatr dziecięcy, samoistna dziedzina młodzieżowo-dziecięcej twórczości artystycznej. Teatr ten opierał się na normalnej zasadzie funkcjonowania sztuki - był teatrem zarobkowym, a więc czymś zgoła innym niż przypadkowe przedstawienia dziecięce czy młodzieżowe, organizowane tylekroć pod patronatem społecznikowskim lub pedagogicznym" (Wierzbowski, 1990, s. 47)9.

Warto to podkreślić i do tej tradycji odwołać się we współczesnych formach edukacji zarówno dzieci, młodzieży jak i dorosłych. Jednak punktem wyjścia musi być świadomość znaczenia tej formy teatru dla polskiej kultury, ale także jej dość wyjątkowego miejsca w tradycji europejskiej. Następnie ważna jest wiedza na temat lalkowego teatru kolędniczego. Szopka pozostawia ogromną przestrzeń do kreacji własnej kolędników, zarówno w warstwie tekstowej, plastycznej, jak i muzycznej. To predestynuje ją do działań edukacyjnych wykorzystujących różne środki artystyczne.

\section{Wartości edukacyjne szopki kolędniczej}

Szopka nie pojawia się jednak w polskiej edukacji, a kultywowane są tylko żywoplanowe jasełka. Dlatego pragnę zwrócić uwagę pedagogów na tę formę teatru lalkowego, który jest nie tylko oryginalny, ciekawy, bardzo polski, ale ma też ogromne walory edukacyjne.

9 Zatem i tu polski teatr lalek znajdował się w odmiennej sytuacji, gdyż w całej Europie teatr bohatera popularnego tworzyły zawodowe trupy lalkarskie lub klany lalkarskie, gdzie profesja przechodziła z pokolenia na pokolenie (np. słynna rodzina Kopecký'ch w Czechach, ród Stražanów na Słowacji czy francuska rodzina Datelin). 
Szopka nie posługiwała się tekstem artystycznym - tworzyły go często osoby niepiśmienne. To samo dotyczy elementów plastycznych, lalek czy muzyki. Istotą przedstawień szopkowych jest odwołanie się do rzeczywistości, do aktualnych wydarzeń danej społeczności, do dowcipnego przedstawienia sytuacji i postaci z elementami karykatury. To znaczy, że przygotowujące szopkę dzieci muszą wyostrzyć swój wzrok, umieć dostrzec coś poza zwykłą codziennością, wartościować wydarzenia, a także umieć ocenić zachowania ludzi. Pisząc wierszowane kwestie czy kuplety dla postaci lalkowych, uczą się wyłapywać tematy i wyrażać swoje myśli w dowcipnych słowach. Opiekun jest po, to by żarty nie wykraczały poza pewne granice przyzwoitości, a także by podpowiadać rozwiązania i inspirować. Teksty szopkowe były zawsze tworzone zespołowo. Jednocześnie teksty dopasowane są do postaci, które wykonuje się z najprostszych materiałów. Kukła, lalka na patyku, jest bardzo prosta, ale daje duże możliwości animacyjne. Zatem dzieci najpierw przygotowują projekty (wymyślają postaci), które później realizują w rzeczywistości jako lalki, by na końcu ożywić je w przestrzeni prostej scenki. Dodatkowym aspektem edukacyjnym jest fakt, że przedstawienie lalkowe żywi się rytmem i muzyką, która powinna być wykonywana „na żywo”, nawet jeśli ma formę niedoskonałą. Wreszcie dochodzi do spotkania zespołu kolędników z publicznością - wybuchy śmiechu, gdy rozpoznawane są postaci i sytuacje, wspólna zabawa i śpiew to nie tylko satysfakcja dla twórców, ale także integracja środowiska, w czasach multimediów - sytuacja nie do przecenienia.
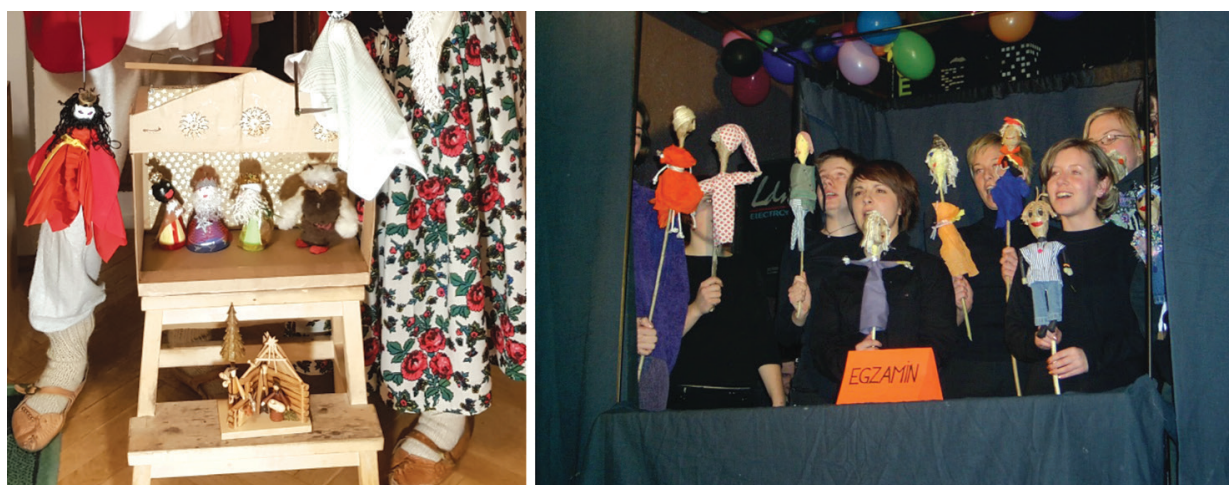

1. Scenka szopkowa wykonana domowym sposobem: z pudełka tekturowego; lalki (w tym wypadku nietradycyjne marionetki na drucie) - brystol + kulki styropianowe + kawałki tkanin + papier kolorowy + drut z wieszaków + pasmanteria.

2. Studenci z wykonanymi przez siebie podczas zajęć kukiełkami; przedstawienie Szopka 2004, UŚ Cieszyn, 7.01.2004. 
Na koniec warto podkreślić terapeutyczny aspekt pracy teatralnej z lalkami. Po pierwsze, każdy znajdzie tu dla siebie miejsce - jako twórca tekstu, konstruktor lalek, muzykant czy animator. Nawet osoby niepełnosprawne czy osoby introwertyczne mogą brać udział w takiej realizacji. Za parawanem łatwo się ukryć, a lalka skupia uwagę na sobie, nie na aktorze ${ }^{10}$.

\section{Zakończenie}

Przyglądając się dziejom powstania teatru lalek, adresującego swoje widowiska do szerokiej publiczności, dostrzegamy niezwykłe przemiany motywów, form i postaci. Pulcinella, włoska postać z commedii dell'arte, przechodząc z kraju do kraju, wypełniała się nowymi treściami zależnie od potrzeb danego narodu, momentu historycznego i splotu politycznych wpływów. Na bazie Pulcinelli powstawały nowe charaktery, tak zrośnięte ze swoimi narodami, że traktowano je jako wytwory kultury własnej. $Z$ angielskim teatrem elżbietańskim było odwrotnie - jego własna konwencja w zderzeniu z europejskim błaznem odmieniła swoje oblicze, nasyciła się nowymi treściami.

Ten złożony proces kulturowy ominął Polskę. Jednak i tu powstał interesujący teatr lalkowy - polska tradycja szopki kolędniczej, choć całkowicie odmienna od europejskiego teatru bohatera popularnego - okazuje się oryginalna, wartościowa i inspirująca. I choć był to teatr nieprofesjonalny, ludowy i sezonowy, spełniał wiele istotnych funkcji społecznych. Integrował Polaków - z jednej strony odwołując się do tradycji religijnej, z drugiej - pokazując samych siebie w parodystycznym ujęciu, wywołując salwy śmiechu, ale także przemycając treści patriotyczne. Szopka kolędnicza okazała się też niezwykle inspirująca - jej forma i budowa dramatyczna przeniknęła do kultury wyższej - korzystali z niej nie tylko twórcy kabaretów, ale artyści miary Wyspiańskiego (np. akt 1 Wesela). Korzystali z niej twórcy teatru dla dzieci, jak warszawski „Baj”, który z kolei zainicjował działalność wielu teatrzyków kukiełkowych na terenie całej II Rzeczypospolitej, a także powstałych po

10 W Bielskim Stowarzyszeniu Artystycznym „Teatr Grodzki” w Bielsku-Białej od lat realizuje się formy teatru lalkowego jako warsztaty dla osób niepełnosprawnych. Okazuje się, że nawet w przypadkach ciężkich upośledzeń fizycznych będących efektem porażenia dziecięcego - dzieci, animując lalkami w trakcie przedstawienia, potrafią pokonać swoje największe ograniczenia i niemożności w stopniu większym niż na ćwiczeniach rehabilitacyjnych (Pokaże ci świat, ilustracja filmowa ćwiczeń, realizacja: K. Tusiewicz, BSA „Teatr Grodzki”, Bielsko-Biała 2001). 
II wojnie światowej (Tomaszewska, 2019). Wreszcie jest to teatr dostępny każdemu i posiadający potencjał edukacyjny i wychowawczy.

Szopka jest niezwykle atrakcyjną spuścizną kultury europejskiej, wydaje się zatem, że należy dołożyć wszelkich starań o utrzymanie tej tradycji żywą.

\section{Bibliografia}

Baron, P. and Cony, G. 2006. Une famille d'opérateurs-marionnettistes les Brioché. http://www.biusante.parisdescartes.fr/sfhm/hsm/ HSMx2006x040x002/HSMx2006x040x002x0203.pdf (20.02.2018).

Edwards, G. „Prof”. 2011. The Art of Punch \& Judy. West Sussex: The Fedora Group.

Jurkowski, H. 2014. Dzieje teatr lalek. Od antyku do belle epoque. Lublin:

Teatr Lalek im. Jana Ch. Andersena.

Jurkowski, H. 1970. Dzieje teatru lalek. Od antyku do romantyzmu. Warszawa: PIW.

Jurkowski, H. 2003. Służba lalek. W: Olbrycht, K. i Pindór, M. red. Teatry narodowe. Tradycja i współczesność/ Národní divadla. Tradice a součestnost. Cieszyn: UŚ - Filia w Cieszynie, ss. 45-53.

Nicoll, A. 1967. W świecie Arlekina. Warszawa: PIW.

Sztaudynger, J.I. i Sztaudynger-Kaliszewiczowa, A. 2009. Chwalipięta czyli rozmowy z Tata, Kraków: Wydawnictwo Literackie.

Tomaszewska, E. 2019. „Skrzaty Cieszyńskie”. O teatrze ochotniczym. Cieszyński Almanach Pedagogiczny. 6, ss. 54-68.

Waszkiel, M. 1990. Dzieje teatru lalek $w$ Polsce (do 1945). Warszawa: IS PAN. Wierzbowski, R. 1990. O szopce. Łódź: Polunima.

\section{The theatre of the popular Western Europe hero and the Polish nativity play}

Abstract: In the $18^{\text {th }}$ century, a number of puppet figures began to gain popularity. They appeared on the traveling scenes of theatre troupes almost throughout Europe. They were comic figures of the character of popular heroes, presented in the streets, squares and markets and speaking to audience in their own language. One part of them came from the comedy dell'arte (Pulcinella, Poliszynel, Guignol, Don Cristobal, and Pietruszka). The theatrical roots of the heroes who appeared in German states (Hanswurst, Kasperle, Kašparek, Gašparko) reached the Elizabethan theatre and are associated with the presence of wandering theatre troups 
of English actors. They combined Elizabethan theatre with traditional figure of a folk jester. Because for Poland it is a time of slow loss of independence for the benefit of neighboring countries, the theatre of the popular hero was not created. Instead, the form of szopka (a nativity play) was developing. Comparison of the functions and significance of these theatrical phenomena is the subject of this study. It is also an attempt to draw the attention of educators to the educational values of the Polish nativity play.

Keywords: szopka (a nativity play), puppet theatre, popular art, folk hero, children's theatre, cabaret 